\title{
JOSE IGNACIO CABRUJAS SE ADUEÑÓ DEL SILENCIO
}

Era sábado 21 de octubre de 1995, cuando en la mar serena de la Isla de Margarita una barca dorada, cargada de flores, de angustias y de sabias, encalló para siempre en el Caribe. En su timón, su único capitán: José Ignacio Cabrujas, uno de los intelectuales más brillantes y controversiales de la Venezuela de este siglo.

Dramaturgo, actor, ensayista, director de teatro, promotor cultural, guionista cinematográfico, hombre de ópera, melómano universal, pionero de la "telenovela cultural" latinoamericana y militante de sueños por un país suyo que imaginaba distinto al caos moral, político y social de estos tiempos de olvidos patrios.

José Ignacio fue un hombre probo, de agudezas y pasiones definitivas que lo llevaron a ejercer un periodismo descarnado - amoroso y perverso - de amor trascendente, al que nos tenía habituados cada semana en la prensa capitalina, a través de sus columnas en "El Diario de Caracas" y en "El Nacional".

Su militancia con el porvenir le viene de los años sesenta, venero causal de la generación más prolífera del quehacer cultural contemporáneo. Por aquel entonces, orienta su vocación teatral en los sótanos rebeldes del Teatro Universitario de la Universidad Central de Venezuela, bajo la direccción de Nicolás Curiel. En ese devenir contestatario lo acompaña inicialmente Román Chalbaud, otro miembro insigne del movimiento teatral, a quien más tarde se le suma Isaac Chocron, para crear "El Nuevo Grupo", soporte fundamental del teatro moderno venezolano.

Esa trilogla creativa - Cabrujas, Chalbaud, Chocrón-, será bautizada y reconocida en Venezuela, como "La Santísima Trinidad", para tipificar la esencialidad teatral de un país entonces emergente, sin olvidar la maestría paterna de Cesar Rengifo y con la mirada en un futuro que permitirá estimular a los nuevos dramaturgos, entre otros a José Gabriel Núnez y a Rodolfo Santana.

De su vasta obra dramática se destacan: "Los insurgentes" (1956), "Juan Francisco De León" (1959), "E1 extraño viaje de Simón El Malo" (1961), "En nombre del Rey” (1963), "Días de poder" (1967), "Fiésole" (1971), "Profundo" (1972), “Acto cultural" (1976), "E1 día que me quieras" (1979), "Noche oriental" (1983), "Autorretrato de un artista con barba y pumpá" (1990) y "Sony" (1995).

Algunas de estas obras han sido montadas en festivales y repertorios habituales de grandes compañías y teatros de América y Europa, testimoniando la universalidad de su temática humana, de ciclos históricos recurrentes; el amor, la guerra, la ambición, el poder, 
las tradiciones, los recuerdos, la heroicidad, los sueños, la creatividad y la locura, figuran en esa ristra de sus preocupaciones por la vida del hombre y su destino, y por el país de su entrañable pertenencia.

"Profundo" y "Noche oriental" fueron adaptadas al cine y está a la espera "Amaneció de golpe", una creación suya que será filmada y dirigida por el destacado cineasta venezolano Carlos Azpúrua.

Como guionista se le reconoce especialmente por haber trastocado la temática banal e intrascendente de la telenovela venezolana, que a partir de "La Señora de Cárdenas" logra proyectar la esencia humana de sus personajes, asertivos e irresolutos, cambiantes en sus vivencias cotidianas y ajenos al estereotipo clasista hombre bueno-rico, mujer pobre de nobles sentimientos. En esa línea de innovación temática, de simultaneidad protagónica, se inscriben también sus afamadas telenovelas "Natalia de 8 a 9" y "La Dueña", de proyección internacional, que vienen a corroborar su vena dramatúrgica, en la caracterización de cada uno de sus personajes jamás presentados como secundarios.

Su pasión por el mundo del espectáculo total, lo lleva a dirigir montajes operísticos y obras teatrales de los más controversiales dramaturgos contemporáneos venezolanos y de los clásicos universales.

Ahora, ante la realidad de su ausencia, el mundo intelectual venezolano debe asumir el compromiso de publicar la totalidad de su densa obra, porque ella encierra valores paradigmáticos, inherentes a su propia honestidad y valentía cuando propicia la denuncia social, en compromiso con los desposeídos -de bienes y saberes culturales- en el escenario teatral de todos, ante la pérdida progresiva de ideales patrios y universales.

Había nacido el 17 de julio de 1937, en la caraqueñísima parroquia de Catia, fiel a su origen y verdades populares. 